\title{
Erratum to tumor-associated macrophages secret exosomal miR-155 and miR-196a-5p to promote metastasis of non-small-cell lung cancer
}

\section{Editorial Office}

Translational Lung Cancer Research

Correspondence to: Editorial Office. Translational Lung Cancer Research. Email: editor@tlcr.org

Submitted Sep 26, 2021. Accepted for publication Sep 27, 2021.

doi: $10.21037 /$ tlcr-2021-4

View this article at: https://dx.doi.org/10.21037/tlcr-2021-4

Erratum to: Transl Lung Cancer Res 2021;10:1338-54

This article that appeared on Page: 1338-1354, Vol 10, No 3 (March 2021) Issue of the Translational Lung Cancer Research (TLCR) (1), unfortunately contained some typos and some images partially overlapped in both Figure $5 B$ and Figure 6E, but the figure legends and in-text citation of the figures remain intact.

The authors confirmed the errors were inadvertently made during the assembly of the raw transwell panels, because the duplicated panels were close to each other. The corrected Figure 5 and Figure 6 are shown below, which does not affect the interpretation or conclusions of this paper.

Figure 5:
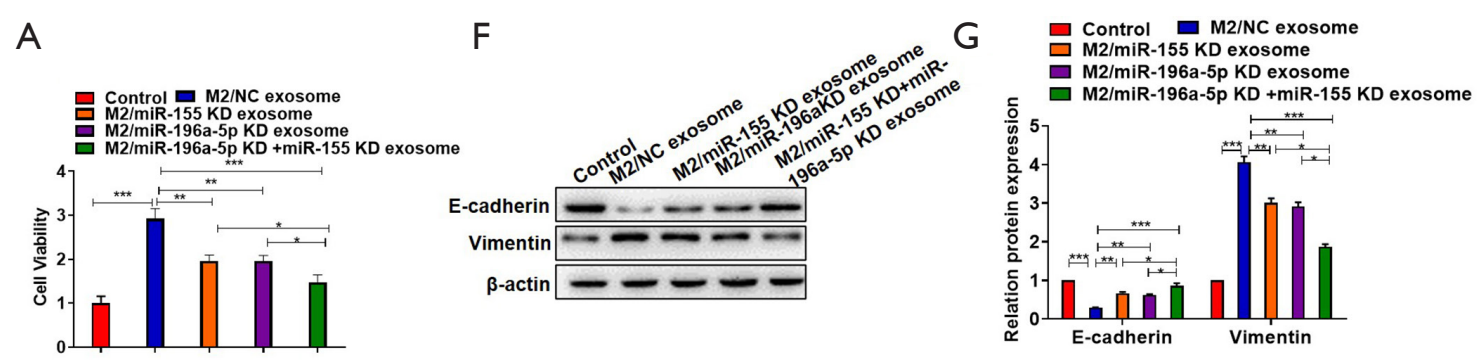

B

\section{C}
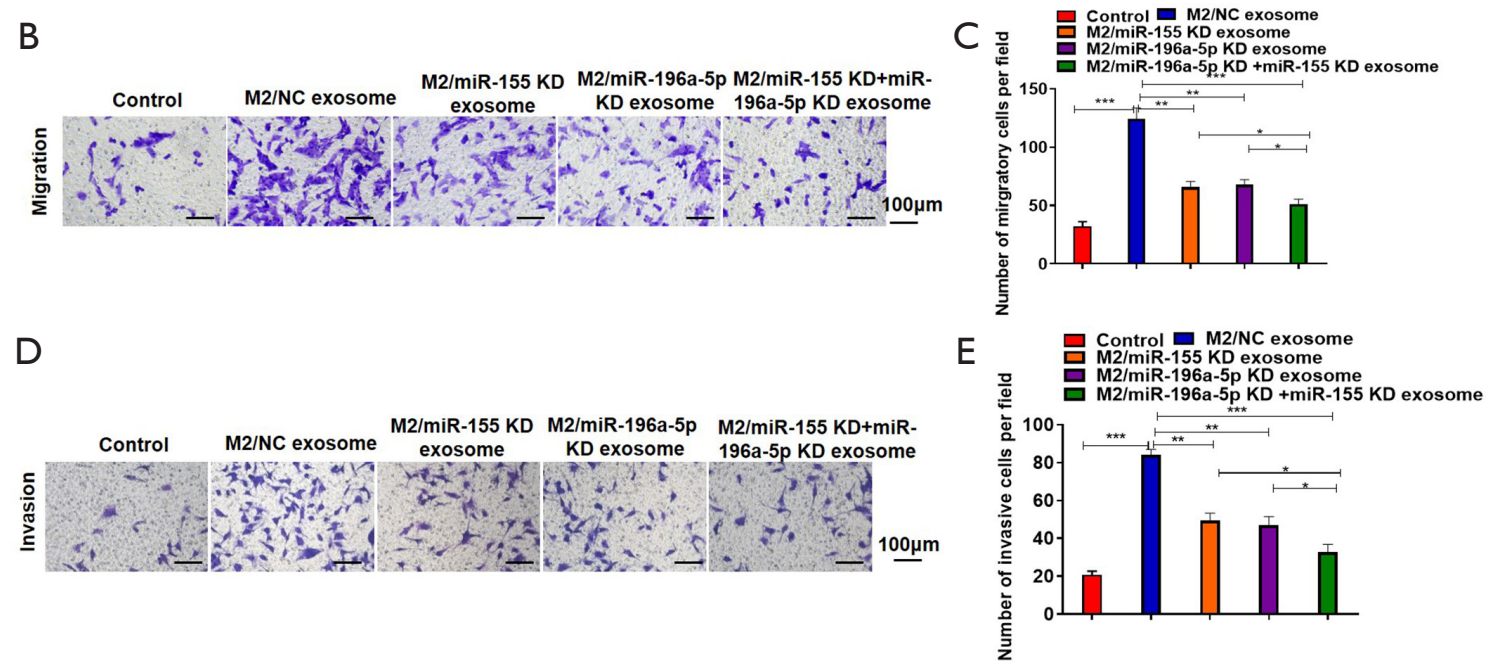
Figure 6:
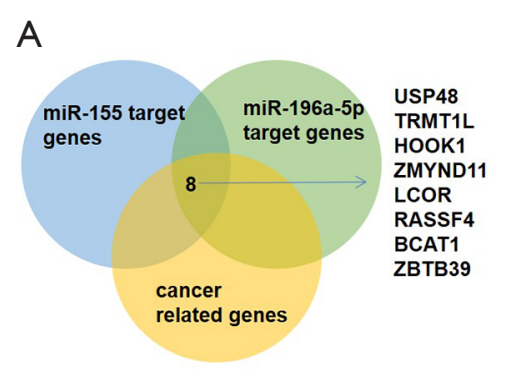

D
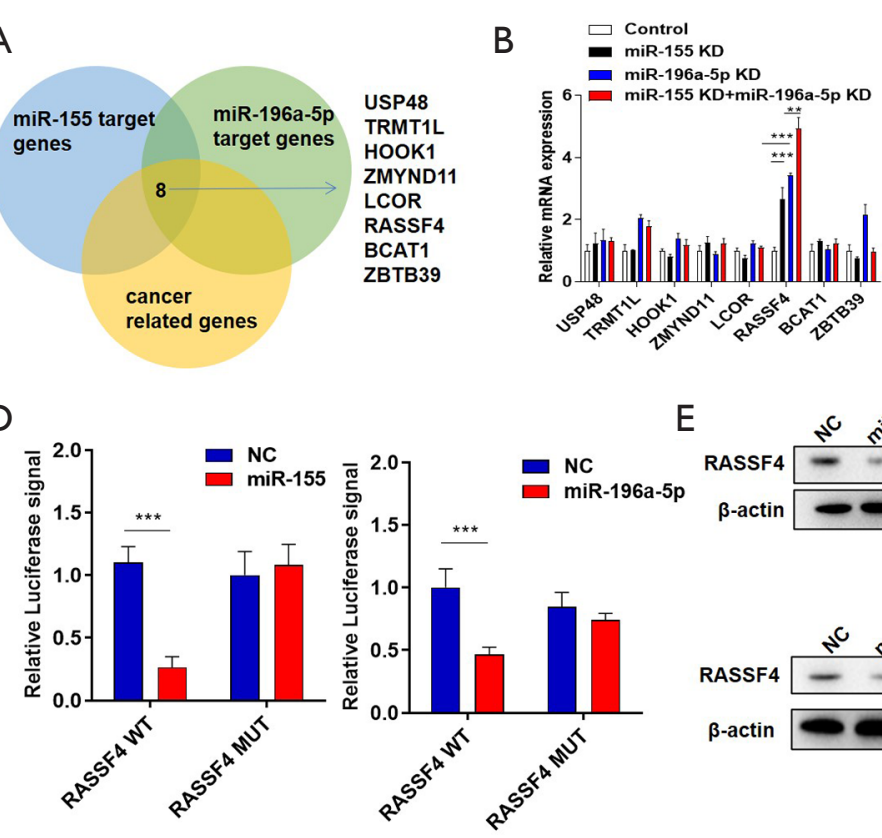
C

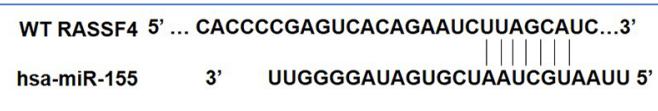
MUT RASSF4 5' ... CACCCCGAGUCACAGAAUCAAUCGUAC...3'

\begin{tabular}{|c|c|}
\hline WT RASSF4 & 5'... CGAGUGCCUGUGUGUCUACCUC....3' \\
\hline hsa-miR-196a-5p 3 & GGGUUGUUGUACUUUGAUGGAU 5, \\
\hline MUT RASSF4 & 5' ... CGAGUGCCUGUGUGUGAUGGAC....3' \\
\hline
\end{tabular}
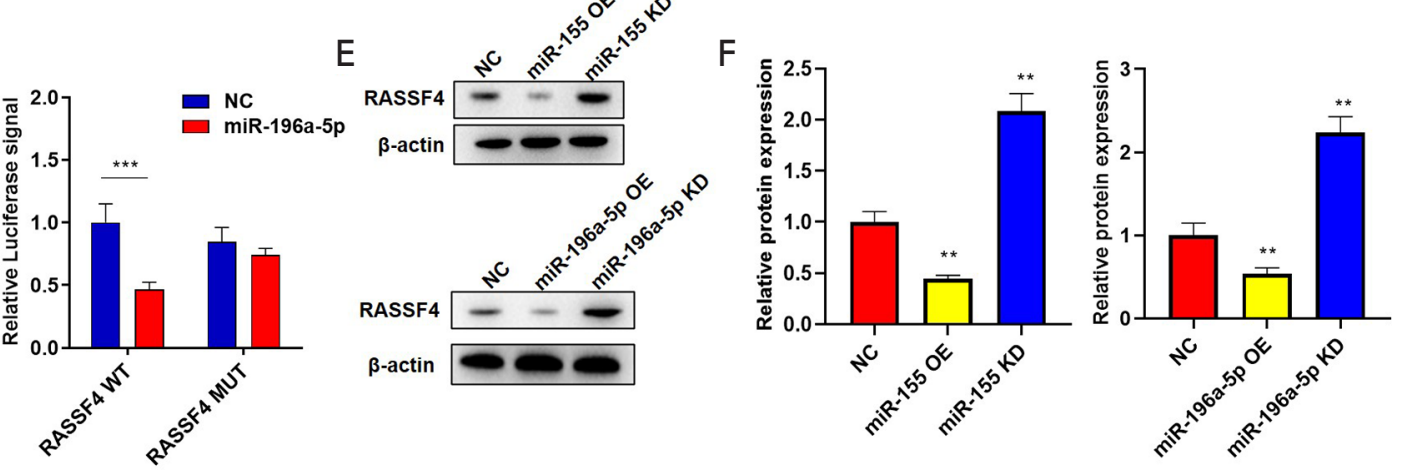

The authors apologize for this error.

Click here to view the updated version of the article.

Open Access Statement: This is an Open Access article distributed in accordance with the Creative Commons AttributionNonCommercial-NoDerivs 4.0 International License (CC BY-NC-ND 4.0), which permits the non-commercial replication and distribution of the article with the strict proviso that no changes or edits are made and the original work is properly cited (including links to both the formal publication through the relevant DOI and the license). See: https://creativecommons.org/ licenses/by-nc-nd/4.0/.

\section{References}

1. Li X, Chen Z, Ni Y, et al. Tumor-associated macrophages secret exosomal miR-155 and miR-196a-5p to promote metastasis of non-small-cell lung cancer. Transl Lung Cancer Res 2021;10:1338-54.

Cite this article as: Editorial Office. Erratum to tumorassociated macrophages secret exosomal miR-155 and miR196a-5p to promote metastasis of non-small-cell lung cancer. Transl Lung Cancer Res 2021;10(10):4047-4048. doi: 10.21037/ tlcr-2021-4 